\title{
The Cleveland Clinic Lou Ruvo Center for Brain Health: Keeping Memory Alive
}

\author{
Jeffrey Cummings*, Kate Zhong and Charles Bernick \\ Cleveland Clinic Lou Ruvo Center for Brain Health, Las Vegas, NV, USA
}

Accepted 21 June 2013

\begin{abstract}
The Cleveland Clinic Lou Ruvo Center for Brain Health (LRCBH) is a unique clinical and translational research enterprise that stems from the passion of Larry Ruvo to honor his father, Lou, a victim of Alzheimer's disease (AD). To attract national attention to $\mathrm{AD}$, Mr. Ruvo convinced architect Frank Gehry to construct the remarkable building complex of the LRCBH in Las Vegas, Nevada. Cleveland Clinic assumed responsibility for running the clinical and research aspects of the LRCBH. The care provided in this novel architectural setting is innovative and emphasizes patients first care with integration of caregiver programs and clinical research opportunities. Standardization of care, outcomes measures, and process metrics provide a platform for assessing, studying, and exporting best practices in cognitive care. Clinical trials empower patients to help solve the diseases that afflict them. The combination of a passionate founder, dramatic architecture, clinical excellence, integrated care partner programs, and commitment to development of next generation treatments makes the LRCBH a unique model of integrated care and research.
\end{abstract}

Keywords: Lou Ruvo center for brain health, cleveland clinic, clinical trials, Frank Gehry, Alzheimer's disease

\section{INTRODUCTION}

The Cleveland Clinic Lou Ruvo Center for Brain Health (LRCBH) is a unique multidimensional enterprise that includes a commitment to "patients first" clinical care, support of care partners, and empowering patients through clinical trials and translational research. The LRCBH is housed in a dramatic Frank Gehry architectural masterpiece situated in the city of Las Vegas and is at the hub of a Cleveland Clinic Alzheimer's Disease Clinical Trial Consortium including sites in Nevada, Ohio, and Florida. How did this unique organization evolve? The heart of the story and prime mover of the enterprise is Larry Ruvo, industry leader and philanthropist, and any description of the LRCBH centers on the commitment of Mr. Ruvo and his wife, Camille, to honoring Larry's father, bringing the best in neurological care to Las Vegas, and finding effective treatments for Alzheimer's disease (AD) and other brain disorders.

${ }^{*}$ Correspondence to: Jeffrey Cummings, MD, ScD, Cleveland Clinic Lou Ruvo Center for Brain Health, 888 West Bonneville Avenue, Las Vegas, NV 89106, USA. Tel.: +1 702483 6029; E-mail: cumminj@ccf.org.

\section{LARRY RUVO}

Larry Ruvo's father, Lou, died of AD in 1994. Lou Ruvo received his care from the late Dr. Leon Thal in San Diego. Appropriate diagnostic and care resources were not available in Las Vegas, a situation Mr. Ruvo vowed to correct. The momentum began in 1996 when a group of friends gathered in Wolfgang Puck's Spago restaurant in Las Vegas donated money to build a program to honor Lou's memory. The ensuing organization was called Keep Memory Alive (KMA). Building on the generosity of his friends, Larry Ruvo began, with Dr. Thal, to plan an AD resource in Las Vegas.

\section{FRANK GEHRY}

Mr. Ruvo, an expert in commercial marketing, knew that calling national attention to $\mathrm{AD}$ was critical to success and saw the master architect, Frank Gehry, as the person most able to "package" AD. The meeting between Larry Ruvo and Frank Gehry is legendary; neither man is known for concession. Mr. Gehry had 
little interest in building in Las Vegas and saw no reason to change his mind; Mr. Ruvo was equally determined. After 3 hours of a planned 45 minute meeting that included Mayor of Las Vegas, Oscar Goodman, the men emerged with a tentative plan. Mr. Gehry's agreement was based in part on his experience with Huntington's disease (HD) and his personal knowledge of the horror of neurodegenerative disorders. He extracted a promise that there would be programs for HD patients at the Center. Planning for the building began in 2006, construction was initiated in 2007, the clinical portion of the campus opened in 2009 , and the activity center with its extravagant canopy was completed in 2010 (Figs. 1-3). The 70,000 square foot building complex was designed in the Gehry studios in Los Angeles, engineered in Germany, fabricated in China, and assembled in Las Vegas. It includes 875.5 tons of steel delivered in 544 individual fabricated elements weighing 2,000-10,000 pounds each and "solved" as a giant 3-dimensional jigsaw puzzle. As an icon and a masterpiece, the Frank Gehry building is the world's most unique clinical and translational research building. The event center is rented for public and private events, adding an important channel of revenue generation for the center's clinical and research activities.

The spectacular architectural setting of the LRCBH is both metaphor and motivator. As a metaphor, the architecture declares that Cleveland Clinic is "building" a unique program and "constructing" the future. As a motivator, thinking in less than innovative terms is a betrayal of the spirit of the building. Frank Gehry was 80 when he created the LRCBH. The LRCBH is a statement of healthy brain aging and the contributions the mature brain can make to science and culture. The architectural setting of the LRCBH is complemented by the presence of original art throughout the building that is displayed and sold on a commission basis as a means of revenue generation for the center. The art further epitomizes the critical role of the brain in cultural and scientific creativity.

\section{LEON THAL, MD, AND ZAVEN KHACHATURIAN, PHD}

The late Dr. Leon Thal was the chair of the Department of Neuroscience at the University of California San Diego (UCSD), Director of the UCSD Alzheimer's Disease Center, and Director of the AD Cooperative Study (ADCS). Dr. Thal served as trusted advisor to Larry Ruvo until his untimely death in an airplane crash in 2007. Dr. Thal was not only a compassionate clinician but also a world leader in clinical research. He promoted the idea of a facility in Las Vegas that went beyond 'care' to include innovative research. He gained Mr. Ruvo's support for this type of facility in Las Vegas as well as the idea of retaining his former mentor and colleague Zaven Khachaturian, $\mathrm{PhD}$, to develop the scientific program in Las Vegas. Dr. Khachaturian, recognized as the Chief Architect of $\mathrm{AD}$ research in the United States, assumed the role of CEO and President of KMA and the Lou Ruvo Brain Institute (LRBI as it was then called).

Dr. Khachaturian's strategic vision for LRBI was endorsed by the Governor and Legislators of Nevada. This support by the State as well as the Ruvo's generosity enabled the institute to organize a series of 'think-tank' style research planning workshops known as Leon Thal Symposia. These meetings led to the publication of several seminal papers which had an important impact on public policy initiatives related to $\mathrm{AD}$ (e.g., the Alzheimer's Study Group [ASG] Report to 111th Congress and the National Alzheimer's Project Act [NAPA] [1, 2]. The concept of a 'Nevada Vital Aging Initiative', comparable to the Framingham Study emphasizing brain health and brain disorders [3], was one of the specific program initiatives that evolved from these 'think-tank' meetings and is now being beta-tested as a proof-of-concept program in the Orange County Vital Aging program in Orange County, California. As Cleveland Clinic assumed responsibility for the clinical activities of the LRCBH, Dr. Khachaturian assumed Emeritus status and continues in an advisory role with LRCBH.

\section{CLEVELAND CLINIC}

Having overcome many obstacles and launched construction of a major medical building in Las Vegas, Mr. Ruvo was faced with the challenge of finding a clinical partner to lend expertise and provide resources to turn a dramatic building into an equally innovative health care resource and research center. Partnerships with several major academic institutions were considered. After a thorough review of these opportunities, Cleveland Clinic emerged as the preferred partner. Delos "Toby" Cosgrove, Chief Executive Officer and President of Cleveland Clinic, met Larry Ruvo in November of 2008. The two men immediately bonded around the shared vision of advancing AD research and care and extending the Cleveland Clinic footprint into the Western United States. Randolph Schiffer, MD, a 


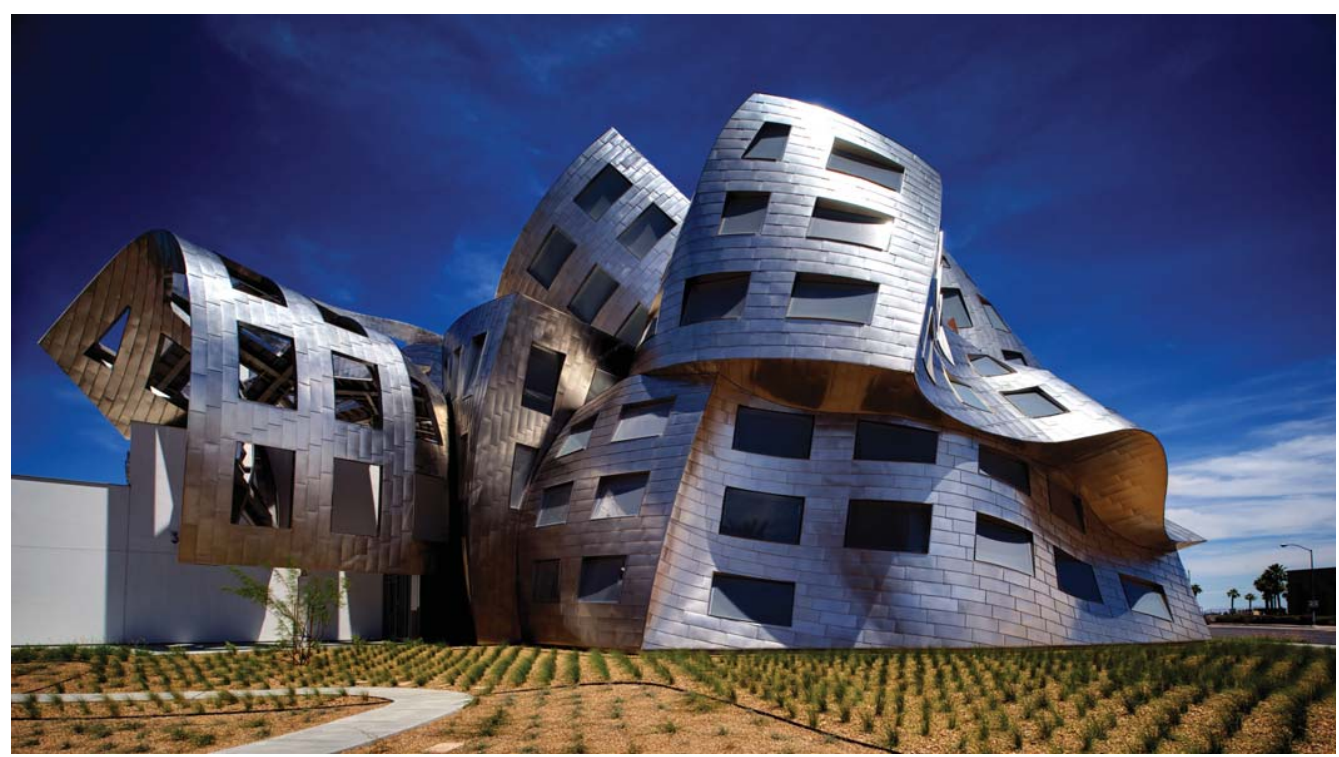

Fig. 1. The canopy covering the activity center of the Frank Gehry building that houses the Cleveland Clinic Lou Ruvo Center for Brain (Matthew Carbone).

neurologist and psychiatrist, provided clinical leadership to the LRCBH during this transitional period. The Clinic's high national regard as an outstanding hospital (4th in the US News and World Report rankings) and its reputation as a leading cardiovascular center, healthcare innovator, and patients first organization all aligned with the Ruvo's aspirations for the LRCBH.

The LRCBH and KMA became Cleveland Clinic entities in February 2009. LRCBH is part of the Neurological Institute (NI) directed by Michael Modic, MD. The NI has a non-traditional structure and is comprised of multiple centers addressing patient-based disorders: AD and neurocognitive disorders in the LRCBH, Parkinson's disease and movement disorders in the Center for Neurological Restoration, multiple sclerosis in the Mellen Center, psychiatric illnesses in the Center for Behavioral Health, among others.

Each NI center has a multidisciplinary team providing interdisciplinary care. The LRCBH includes neurologists, psychiatrists, geriatric psychiatrists, geriatricians, neuropsychologists, psychologists, social workers, and physical therapists. The integration of neurology, psychiatry, and geriatrics is a fundamental tenet of the LRCBH philosophy. The team is supported by administrative, financial, media, marketing, development, engineering, and event staff critical to LRCBH's success. The LRCBH is led by Jeffrey Cummings, $\mathrm{MD}, \mathrm{ScD}$, and the clinical trials program is led by Xue (Kate) Zhong, MD, MSc.

\section{CLEVELAND CLINIC LRCBH AND NEW THINKING ABOUT THINKING}

Innovation pervades the LRCBH and "New Thinking About Thinking" is the prevailing philosophy. From the Gehry building, to the prominent role of philanthropy, the organization of patient care, the emphasis on metrics and outcomes, the integration of neurology and psychiatry, and the approach to research, the LRCBH seeks novel ways of addressing the challenges of providing excellent neurocognitive care and advancing research. Together LRCBH had approximately 7,500 patient visits to physicians in 2012 representing 1,500 new patients, and all services of the LRCBH together had 15,000 patient and family visits in 2012. The goal of the LRCBH is to become the premier solutions provider for neurocognitive care and a leader in advancing clinical trials, experimental therapeutics, and translational research (Table 1).

The inclusion of several therapeutic areas-AD, frontotemporal dementia, Parkinson's disease, HD, multiple sclerosis - is part of the conceptual framework that guides the LRCBH. Brain diseases share common neurobiological features such as neurodegeneration and inflammation and have shared challenges in translational research including patient recruitment, clinical trial design, trial outcomes, and implementation of biomarkers. Many types of biomarkers, as well as some drug therapies, are used across disease states. 
Table 1

Innovative aspects of the clinical and research programs of the Cleveland Clinic Lou Ruvo Center for Brain Health

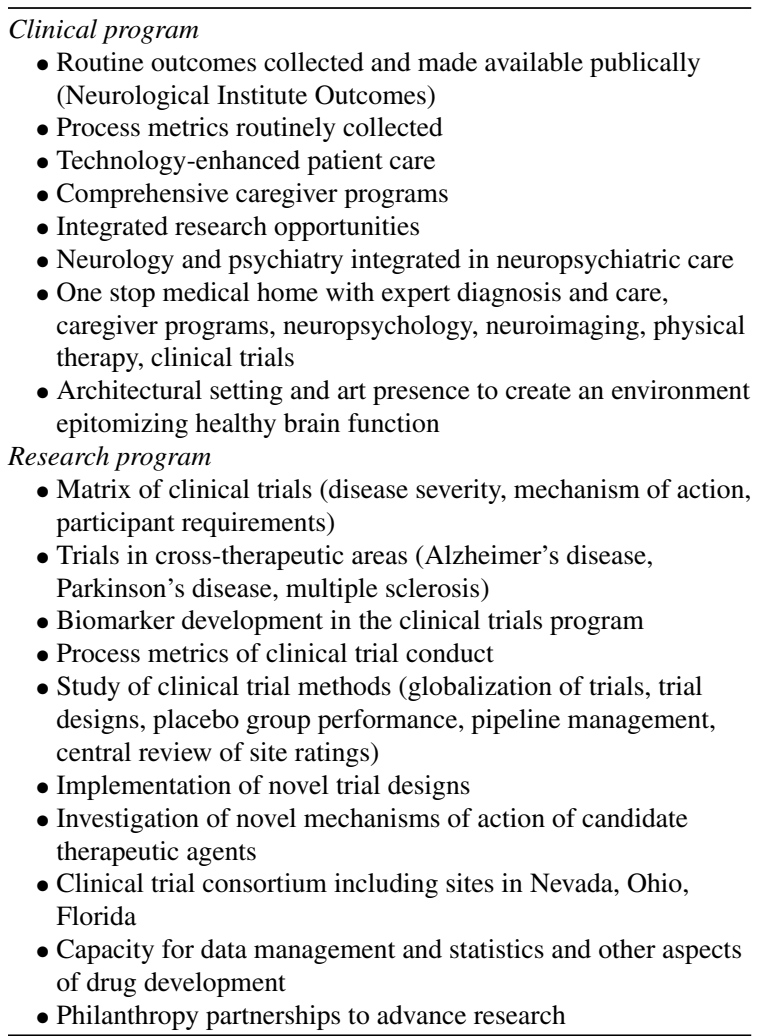

Cross-disease learning is facilitated by the LRCBH organization.

Delivery of expert care to rural areas is a problem faced by many health care organizations. To help provide needed specialty services more broadly in Nevada, LRCBH provides telehealth consultation to cities in the northern portion of the State using advanced telemedicine equipment.

The Las Vegas LRCBH is a one-stop center and medical home providing expert diagnosis, longitudinal care, neuropsychology, neuropsychiatry, physical therapy, brain imaging (magnetic resonance imaging, positron emission tomography), and research opportunities. Patient outcomes are monitored and published annually in the Neurological Institute Outcomes report.

\section{INTEGRATED AND AFFILIATED PROGRAMS}

\section{Alzheimer's disease clinical trial consortium}

Clinical trials are central to the scientific program of the LRCBH. The high patient volume, standardized assessment, and electronic medical records (EMR) of the Cleveland Clinic facilitate patient recruitment. The clinical trial enterprise in the United States is fragmented, poorly organized, error prone, and has to be reconstructed for each trial; site choice is typically driven by volume, not quality [4,5]. Despite these compromises, patient recruitment rarely meets its targeted goals. Radical changes are needed and one foreseeable approach is to have trials embedded in large health care organizations such as the Cleveland Clinic, allowing volume and quality to be achieved. The LRCBH represents an experiment in this organizational approach. LRCBH includes four sites: Las Vegas, Main Campus in Cleveland, Lakewood Campus in Cleveland, and Weston, Florida. The alignment of all clinical programs under a single leadership allows each program to make unique contributions while leveraging the efficiencies of scale of the consortium.

The scientific contributions of the LRCBH focus on advancing therapeutics and trial methods including globalization of trials [6], novel trial designs [7], placebo group characteristics [8], relationship of preclinical models to clinical outcomes [9], repurposing drugs for AD treatment [10] and new therapies to optimize patient care $[11,12]$. The goal of the LRCBH trials program is to be transformative in improving the quality and productivity of clinical trials.

The LRCBH has forged scientific relationships to advance their research programs. Nobelist Stanley B. Prusiner, MD, chairs the scientific advisory board of the LRCBH and provides guidance on the development of the scientific program [13]. Cleveland Clinic resources and preferred partner relationships allow the $\mathrm{LRCBH}$ to provide diverse services to trial sponsors and drug development programs.

\section{Cleveland Clinic Lerner Research Institute}

The Lerner Research Laboratories of the Cleveland Clinic support basic science research activities directed toward understanding AD. Bruce Lamb, MD, uses transgenic mouse models as tool organisms to study AD [14]. Sanjay Pimplikar, PhD, studies amyloid- $\beta$ $(A \beta)$ protein metabolism and intracellular $A \beta$ toxicity [15]. Raquiang Yan, $\mathrm{PhD}$, investigates the function of amyloid- $\beta$ protein precursor cleavage site enzyme (BACE1) activity [16, 17]. The Lerner laboratories also house investigators addressing basic aspects of neuroinflammation and neurodegeneration including Bruce Trapp, PhD, and Richard Ransohoff, PhD [16, $18,19]$. These basic research activities interface with 


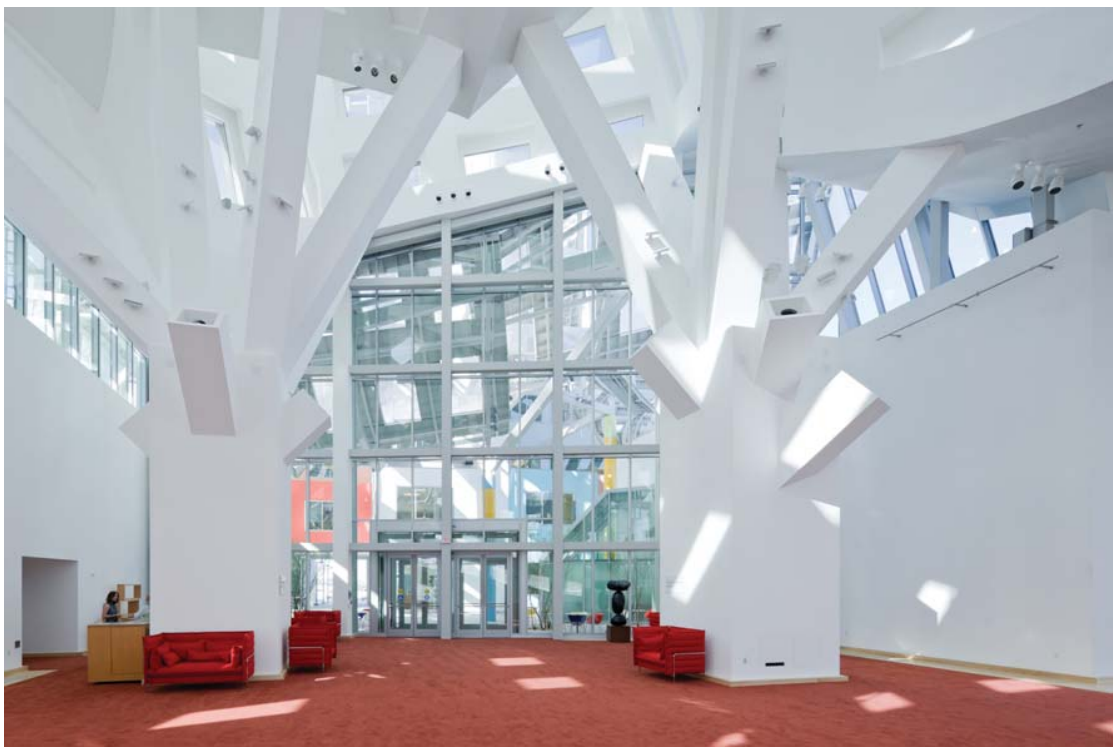

Fig. 2. The interior of the activity center (Iwan Baan)

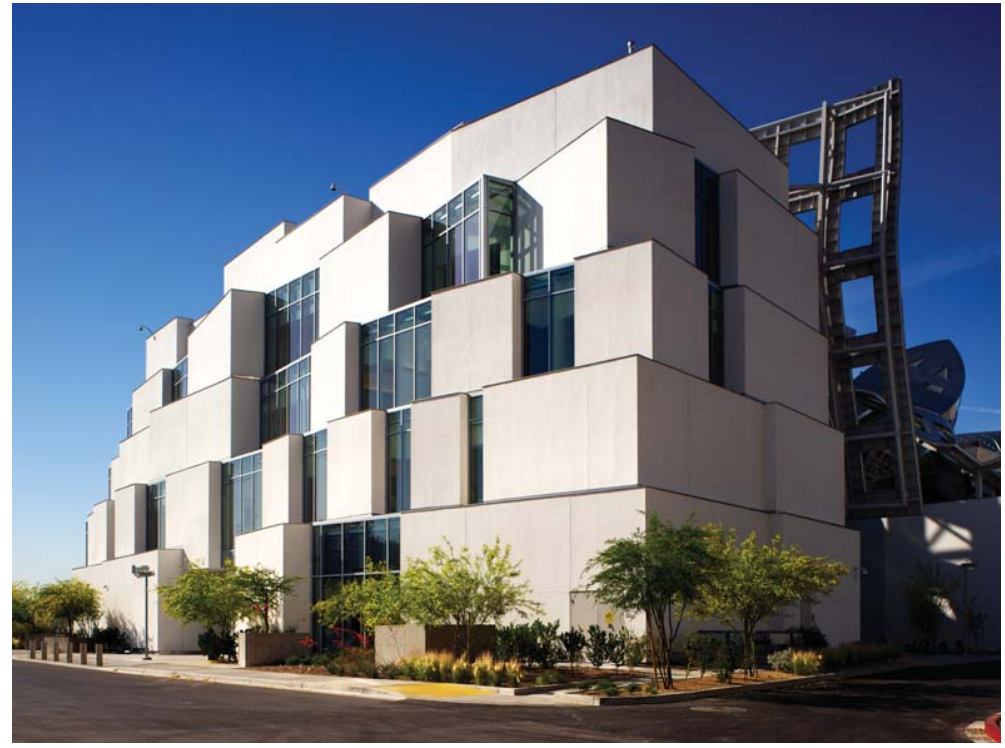

Fig. 3. The exterior of the clinical, research, and administrative building (Matthew Carbone).

the clinical and translational research programs of the LRCBH.

\section{Schey center for neurocognitive imaging}

The Schey Center for Cognitive Neuroimaging, directed by Stephen $\mathrm{Rao}, \mathrm{PhD}$, is a key component of the LRCBH on the Cleveland Clinic campus. The program focuses on using functional MRI (fMRI) to explore cognition and neurocognitive disorders including $\mathrm{AD}$, mild cognitive impairment, post-bypass surgery syndromes, and HD [20-22].

Professional fighters brain health study

Las Vegas is the site of many boxing matches and mixed martial arts contests with over 800 registered combatants. With the support of a grant from the Lincy 
Foundation and support from fight promotors, Charles Bernick, MD, leads a Fighters Brain Health Study with annual cognitive assessments and MRI examinations. The goal of the study is to assess the short and longterm consequences of fighting and to determine which fighters are at risk for chronic progressive traumatic encephalopathy [8]. The study will empower athletes to make informed decisions based on knowledge of their risks for cognitive decline. Over 350 fighters have been assessed and longitudinal examinations are under way. This research program also includes a retired athletes clinic and comprehensive assessment of neurocognitive disorders occurring in former football players in a program sponsored by the National Football League Players Association. Lessons derived from these activities will be extrapolated to head injury sustained in other types of sports and to military and civilian head injury.

\section{Parkinson's disease exercise study}

LRCBH is one site in the multisite study of the effects of exercise on Parkinson's disease led by Jay Alberts, PhD. Motor function and fMRI measures comprise the outcomes of this study designed to find non-pharmacological means of improving motor function in Parkinson's disease patients [23].

\section{Scientific conferences}

The LRCBH sponsors think tank meetings and scientific conferences aimed at identifying and resolving barriers to development of $\mathrm{AD}$ therapies. A conference sponsored jointly with the Association for Frontotemporal Degeneration on animal models of tauopathies focused on preclinical models of tau protein disorders and how best to develop new therapeutics for tau-related diseases [24, 25]. A conference on chronic traumatic encephalopathy (CTE) co-sponsored with Boston University was the first national conference on the chronic progressive tau-related disorder occurring in athletes and soldiers subjected to blast injuries. The Surgeon General of the United States, Regina Benjamin, MD, addressed the conference and embraced the study of CTE as part of her disease prevention platform.

\section{PHILANTHROPY AND FUNDING}

Science is resource-intensive and multiple sources of revenue are required to advance the translational science agenda of the LRCBH. Levels of National Institutes of Health (NIH) funding are declining and federal sources cannot suffice by themselves to support the research enterprise. State support is stressed by current economic circumstances. Successful programs must diversify and innovate around revenue sources. Philanthropy is an important means of insuring the success of scientific programs. Individual philanthropy and the activities and events of KMA are keys to the financial success of the LRCBH. The annual gala, rodeo, sponsored events, activity center, productrelated revenue (such as the Wolfgang Puck Wires) and art sales generate funds that are applied to capital expenses, clinical programs, and research. In total, over $\$ 100$ million in private philanthropy have been raised to support the construction and operations of the LRCBH. This represents a model collaboration between philanthropists, scientists, and clinicians to advance innovative clinical programs and research.

\section{CONCLUSION}

The LRCBH is a unique integrated care and research organization. Its care is personal (patients first), predictive (excellent diagnostics and therapeutics), and participatory (involves patients in clinical trials and other center activities). Outcomes, metrics and standardization of carepaths are the basis for defining best clinical practices. LRCBH entails a consortium of sites and represents a novel comprehensive organization for advancing clinical trials. Care partner programs are integrated into all aspects of care and research. The complex interface between brain and behavior is incorporated into the philosophical and operational underpinnings of the LRCBH. The Center is advancing a translational research agenda and supporting research to solve brain diseases representing a major threat to the public health. LRCBH is committed to New Thinking about Thinking. Through studies of the clinical trial process, the LRCBH will exert a transformative influence for improved quality on the clinical trial and drug development enterprise. LRCBH reflects the determination of Larry Ruvo and his wife Camille to honor Larry's father and to Keep Memory Alive.

\section{DISCLOSURE STATEMENT}

Authors' disclosures available online (http://www.jalz.com/disclosures/view.php?id=1843).

\section{REFERENCES}

[1] Khachaturian ZS, Snyder PJ, Doody R, Aisen P, Comer M, Dwyer J, Frank RA, Holzapfel A, Khachaturian AS, Korczyn 
AD, Roses A, Simpkins JW, Schneider LS, Albert MS, Egge R, Deves A, Ferris S, Greenberg BD, Johnson C, Kukull WA, Poirier J, Schenk D, Thies W, Gauthier S, Gilman S, Bernick C, Cummings JL, Fillit H, Grundman M, Kaye J, Mucke L, Reisberg B, Sano M, Pickeral O, Petersen RC, Mohs RC, Carrillo M, Corey-Bloom JP, Foster NL, Jacobsen S, Lee V, Potter WZ, Sabbagh MN, Salmon D, Trojanowski JQ, Wexler N, Bain LJ (2009) A roadmap for the prevention of dementia II: Leon Thal Symposium 2008. Alzheimers Dement 5, 85-92.

[2] Khachaturian ZS, Barnes D, Einstein R, Johnson S, Lee V, Roses A, Sager MA, Shankle WR, Snyder PJ, Petersen RC, Schellenberg G, Trojanowski J, Aisen P, Albert MS, Breitner JC, Buckholtz N, Carrillo M, Ferris S, Greenberg BD, Grundman M, Khachaturian AS, Kuller LH, Lopez OL, Maruff P, Mohs RC, Morrison-Bogorad M, Phelps C, Reiman E, Sabbagh M, Sano M, Schneider LS, Siemers E, Tariot P, Touchon J, Vellas B, Bain LJ (2010) Developing a national strategy to prevent dementia: Leon Thal Symposium 2009. Alzheimers Dement 6, 89-97.

[3] Thal L, Kuller L, Bowman K, Breitner J, Evans D, Farrer L, Frank R, Khachaturian AS, Khachaturian ZS, Kukull W, Nieto J, Petersen R, Sager M, Scherr P, Bain LJ (2007) The Nevada Vital Aging Initiative: A private-public partnership to study early predictors of dementia. Alzheimers Dement $\mathbf{3}$, 62-67.

[4] Becker RE, Greig NH, Giacobini E (2008) Why do so many drugs for Alzheimer's disease fail in development? Time for new methods and new practices? J Alzheimers Dis 15, 303325.

[5] Fillit HM, O'Connell AW, Brown WM, Altstiel LD, Anand R, Collins K, Ferris SH, Khachaturian ZS, Kinoshita J, Van Eldik L, Dewey CF (2002) Barriers to drug discovery and development for Alzheimer disease. Alzheimer Dis Assoc Disord 16, S1-S8.

[6] Cummings J, Reynders R, Zhong K (2011) Globalization of Alzheimer's disease clinical trials. Alzheimer's Res Ther $\mathbf{3}$, 24-33.

[7] Cummings Jl, Gould H, Zhong K (2012) Advances in designs for Alzheimer's disease in clinical trials. Am J Neurodegener Dis 1, 205-216.

[8] Bernick C, Cummings J, Raman R, Sun X, Aisen P (2012) Age and rate of cognitive decline in Alzheimer disease: implications for clinical trials. Arch Neurol 69, 901-905.

[9] Sabbagh JJ, Kinney JW, Cummings JL (2012) Animal systems in the development of treatments for Alzheimer's disease: challenges, methods, and implications. Neurobiol Aging 34, 169-183.

[10] Appleby B, Nacopoulos D, Milano N, Zhong K, Cummings J (2013) A review: treatment of Alzheimer's disease discovered in repurposed agents. Dementia Geriatr Cog Disorder 35, $1-22$.

[11] Cummings JL, Banks SJ, Gary RK, Kinney JW, Lombardo JM, Walsh RR, Zhong K (2013) Alzheimer's disease drug development: Translational neuroscience strategies. CNS Spectr 18, 128-138

[12] Pioro EP, Brooks BR, Cummings J, Schiffer R, Thisted RA, Wynn D, Hepner A, Kaye R; Safety, Tolerability, and Efficacy Results Trial of AVP-923 in PBA Investigators (2010) Dextromethorphan plus ultra low-dose quinidine reduces pseudobulbar affect. Ann Neurol 68, 693-702.

[13] Prusiner SB (2012) Cell biology. A unifying role for prions in neurodegenerative diseases. Science 336, 1511-1513.
[14] Vidal R, Sammeta N, Garringer HJ, Sambamurti K, Miravalle L, Lamb BT, Ghetti B (2012) The Psen1-L166P-knock-in mutation leads to amyloid deposition in human wild-type amyloid precursor protein YAC transgenic mice. FASEB $J$ 26, 2899-2910.

[15] Ghosal K, Stathopoulos A, Thomas D, Phenis D, Vitek MP, Pimplikar SW (2013) The apolipoprotein-E-mimetic COG112 protects amyloid precursor protein intracellular domain-overexpressing animals from Alzheimer's diseaselike pathological features. Neurodegener Dis 12, 51-58.

[16] Luo X, Prior M, He W, Hu X, Tang X, Shen W, Yadav S, Kiryu-Seo S, Miller R, Trapp BD, Yan R (2011) Cleavage of neuregulin-1 by BACE1 or ADAM10 protein produces differential effects on myelination. J Biol Chem 286, 23967-23974.

[17] Zhou X, Hu X, He W, Tang X, Shi Q, Zhang Z, Yan R (2011) Interaction between amyloid precursor protein and Nogo receptors regulates amyloid deposition. FASEB J 25, 3146-3156.

[18] Dutta R, Trapp BD (2011) Mechanisms of neuronal dysfunction and degeneration in multiple sclerosis. Prog Neurobiol 93, 1-12.

[19] Ransohoff RM, Brown MA (2012) Innate immunity in the central nervous system. J Clin Invest 122, 1164-1171.

[20] Aylward EH, Liu D, Nopoulos PC, Ross CA, Pierson RK, Mills JA, Long JD, Paulsen JS; PREDICT-HD Investigators and Coordinators of the Huntington Study Group (2012) Striatal volume contributes to the prediction of onset of Huntington disease in incident cases. Biol Psychiatry 71, 822-828.

[21] Woodard JL, Sugarman MA, Nielson KA, Smith JC, Seidenberg M, Durgerian S, Butts A, Hantke N, Lancaster M, Matthews MA, Rao SM (2012) Lifestyle and genetic contributions to cognitive decline and hippocampal structure and function in healthy aging. Curr Alzheimer Res 9, 436-446.

[22] Sugarman MA, Woodard JL, Nielson KA, Seidenberg M, Smith JC, Durgerian S, Rao SM (2012) Functional magnetic resonance imaging of semantic memory as a presymptomatic biomarker of Alzheimer's disease risk. Biochim Biophys Acta 1822, 442-456.

[23] Ridgel AL, Kim CH, Fickes EJ, Muller MD, Alberts JL (2011) Changes in executive function after acute bouts of passive cycling in Parkinson's disease. J Aging Phys Act 19, 87-98.

[24] Boxer AL, Gold M, Huey E, Hu WT, Rosen H, Kramer J, Gao FB, Burton EA, Chow T, Kao A, Leavitt BR, Lamb B, Grether M, Knopman D, Cairns NJ, Mackenzie IR, Mitic L, Roberson ED, Van Kammen D, Cantillon M, Zahs K, Jackson G, Salloway S, Morris J, Tong G, Feldman H, Fillit H, Dickinson S, Khachaturian ZS, Sutherland M, Abushakra S, Lewcock J, Farese R, Kenet RO, Laferla F, Perrin S, Whitaker S, Honig L, Mesulam MM, Boeve B, Grossman M, Miller BL, Cummings JL (2013) The advantages of frontotemporal degeneration drug development (part 2 of frontotemporal degeneration: the next therapeutic frontier). Alzheimers Dement 9, 189-198.

[25] Boxer AL, Gold M, Huey E, Gao FB, Burton EA, Chow T, Kao A, Leavitt BR, Lamb B, Grether M, Knopman D, Cairns NJ, Mackenzie IR, Mitic L, Roberson ED, Van Kammen D, Cantillon M, Zahs K, Salloway S, Morris J, Tong G, Feldman H, Fillit H, Dickinson S, Khachaturian Z, Sutherland M, Farese R, Miller BL, Cummings J (2013) Frontotemporal degeneration, the next therapeutic frontier: molecules and animal models for frontotemporal degeneration drug development. Alzheimers Dement 9, 176-188. 